\title{
The balance scale
}

\author{
A matter of life and death.
}

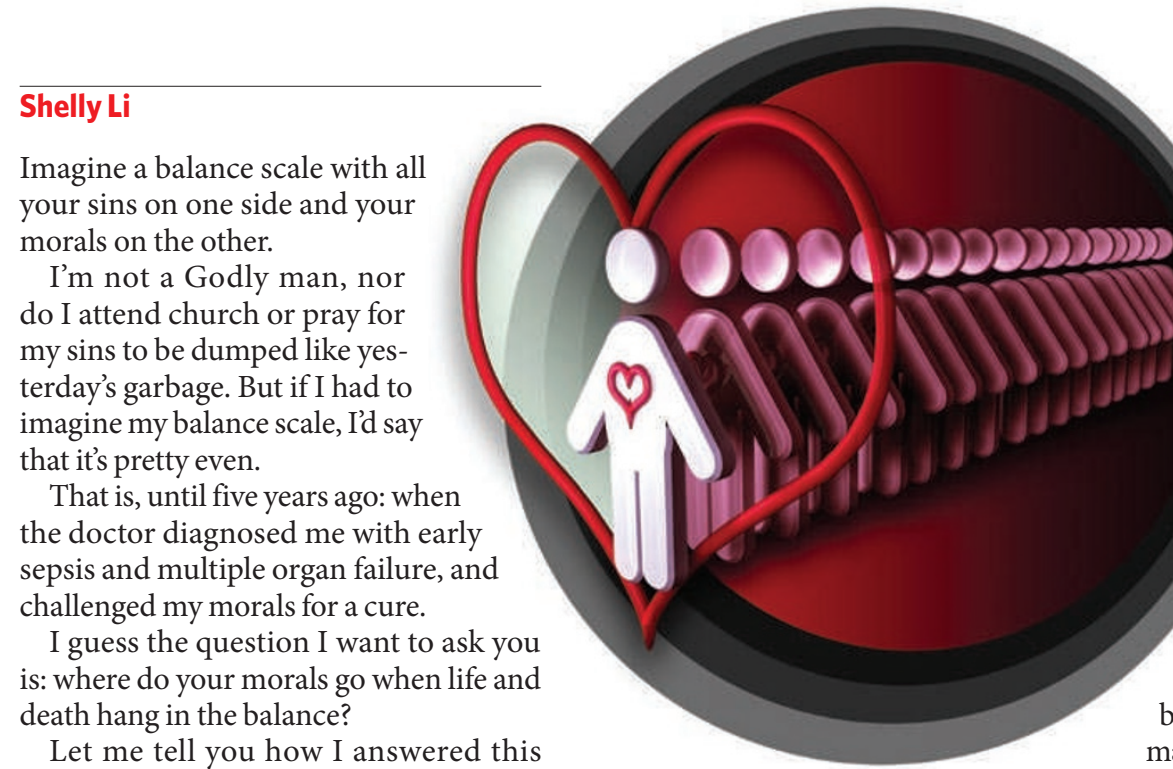

Let me tell you how I answered this question.

After my fall from the roof in 2045, I spent close to a week in a hospital bed. Annie and I had been hanging Christmas lights, and I set my weight on a loose shingle and came tumbling down.

I thought I had recovered perfectly. I still felt sore, sure, but I was moving, and I wanted to go home and spend Christmas with Mum, Dad and the cousins.

But Dr Pei - he'd been my physician for almost 20 years - insisted that he run a few more tests. "Something isn't quite right," he told me. "I have a feeling."

And so I let him run more tests.

The week after, he came into my room and delivered the news.

"Early sepsis," he said.

I frowned, so he spoke words that I understood. Bacterial infection. Inflammatory response. An exhausted immune system.

Sitting beside me, Annie started to cry. She reached out to grab my hand, her fingers shaking.

But Dr Pei continued. Eventually the sepsis would lead to multiple organ failure. My lungs, liver, kidneys, heart. Consider them gone. "This is serious," Dr Pei said. "This is fatal."

The information rammed into my gut like a cold fist, hurting me to a degree that no physical wound could. The thought of dying, lying in a casket aged 42 , scared me.

I leaned over and, rubbing Annie's back, told her to go and get a cup of coffee. She had heard all she needed and shouldn't have to stay. Her suffering support would hurt me more than her absence.

After the door slid closed behind her, I asked Dr Pei how long I had to live.
"We will do all that we can to keep the toxins at bay," he said. "In the best scenario, you can go on living for a few more years, but you will never be able to leave the confines of a hospital. Most likely, though, the sepsis will advance to a fatal stage in a matter of weeks."

A matter of weeks. The words echoed through my head over and over, as the room began to spin. I was beginning to wonder what I would do with my remaining time when Dr Pei said a cure had been developed recently.

"What? You said that sepsis was fatal."

"Yes, but there are certain ways to, ahh, cheat death." Dr Pei paused. I felt a shiver travel down my spine.

"There's a human cloning company in St Louis," the doctor said. "Officially, their intent is to offer homosexual or infertile couples the chance to have a genetically identical child. But I know a geneticist there, and they have done cloning to isolate and alter DNA to get rid of diseasecausing genes. Combined with accelerated growth, BioClone can produce for you the organs necessary to escape the fatalities of sepsis."

And with those words, silence fell over the room as I stared at Dr Pei; him at me. Did he just suggest that I clone myself and harvest the organs?

I asked him what would happen to the clone, once the organs were retrieved.

He told me that I already knew the answer to this question.

Like I said, I'm not a religious man, and I'm pro-choice, but the thought of a creating clone, a living, breathing body identical to me, and then killing it so that
I could live a long, healthy life ... it felt soulless.

"I will give you BioClone's number, and the name of my friend," Dr Pei finally said. “Tell him that I sent you, and he will help you from there." The doctor smiled sadly as he handed me a slip of paper. "The choice, however, is yours."

As soon as he finished speaking, the door slid open again, and Annie's face appeared before me. Her puffy eyes were red, her mascara smeared. But the way she looked at me, that hopeless stare that

I knew would haunt me to death and beyond, I realized that this choice I had to make, it would not be for me alone. Could I compromise my morals to save Annie from the pain that my death would cause?

This is my story, and my existence is my answer.

Since the diagnosis of sepsis, I have got quite used to life here at the hospital. The nurses are always friendly to me, and the "I'm a dying man" excuse never fails to get me the last cookie on the plate or the TV channel I want to watch.

Outside the window, snow is floating down from the sky, melting the moment the flakes hit the ground. The sight is beautiful nevertheless.

I turn and, moving the blood pressure monitor, look over at Annie, asleep on the couch. A small smile touches her lips as she adjusts her position under the blanket.

I cannot tear my eyes away, and I cannot stop smiling myself.

They say that death makes a man realize things he has never fathomed before.

Now I know that my balance scale is not at all a battle between my sins and my morals. My balance scale is a perfect parity of death and time.

Death is the limit, the end, and it is there so that I can make the most of this space of time, from the moment I am born to the moment I draw my last breath.

I don't need to prolong the inevitable, for I have made my life beautiful with love. And love is a weight that nothing in this world can balance.

This story was born thanks to the beautiful brain of Shelly's best friend. When Shelly is not picking thoughts out of others' heads, she can be found at www.shelly-li.com.

Join the discussion of Futures in Nature at go.nature.com/QMAm2a 